Bangladesh J. Bot. 44(2): 193-200, 2015 (June)

\title{
PERFORMANCE OF TOMATO (LYCOPERSICON ESCULENTUM MILL.) GERMPLASM TO SALINITY STRESS
}

\author{
MA Siddiky ${ }^{1}$, MS KHAN ${ }^{2}$, Md Mostafizur Rahman ANd M KHABIR UdDin* \\ Department of Environmental Sciences, Jahangirnagar University, Dhaka-1342, Bangladesh
}

Key words: Tomato germplasm, Salt tolerance, Dry matter, Ion concentration

\begin{abstract}
A solution culture experiment was conducted to screen out 16 Bangladeshi tomato germplasm for salinity tolerance with respect to severity of leaf symptoms, shoot and root dry matter production, fruit yield, shoot $\mathrm{Na}^{+}, \mathrm{K}^{+}, \mathrm{Ca}^{2+}$ accumulation and their respective ratios by exposing up to $120 \mathrm{mM} \mathrm{NaCl}$. The salinity tolerance scale ranged from 1.0 (most tolerant) to 3.5 (most sensitive). Based on the severity of leaf symptoms, "BT14 (BARI Tomato 14)" and "BHT5 (BARI Hybrid Tomato 5)" were found to be most tolerant germplasm to salinity with score 1.0. Reduction of dry weight was found to be $19 \%$ (shoot) and $15 \%$ (root) in BT14 and BHT5, 30 - 76\% (shoot) and 27 - 83\% (root) in other germplasm. Higher correlation was found between salinity tolerance scale classes and the reduction of shoot/root dry weight, $\mathrm{Na}^{+}$concentration, $\mathrm{K}^{+} / \mathrm{Na}^{+}$, and $\mathrm{Ca}^{2+} / \mathrm{Na}^{+}$ratios in BT14 and BHT5 germplasm. The fruit yield of BT14 and BHT5 germplasm was less and decreases with high salinity. Thus, "BT14" and "BHT5" can be regarded as a breeding material for development of new tomato varieties resistant to salinity.
\end{abstract}

\section{Introduction}

In Bangladesh the availability of vegetables is only about 20 per cent of the recommended requirement of $200 \mathrm{~g} /$ person/day. Average tomato production in the world is $26.29 \mathrm{t} / \mathrm{ha}$, whereas in Bangladesh it is only $6.46 \mathrm{t} / \mathrm{ha}$ (FAO 2011). Siddiky et al., (2012) observed 13 tomato germplasm in a saline soil of Khulna, Bangladesh and recorded the fruit yield (60 t/ha) in 2 - 8 $\mathrm{dS} / \mathrm{m}$ (non saline to moderate saline) but in $8.1-12 \mathrm{dS} / \mathrm{m}$ (moderately higher saline) yield was reduced $50 \%$.

In Bangladesh, coastal areas are about 2.86 million ha covering by $30 \%$ of the total crop land. Of this, nearly 1.056 million ha cultivable land are affected by varying degrees of salinity and $75 \%$ cultivated land (very low to moderate salinity) have scope for successful crop production (SRDI 2010). Increasing evidence suggests that plant species and varieties vary greatly in their resistance to salinity (Ashraf and Foolad 2007). The tomato plant is moderately tolerant to salinity stress (Ayers and Westcot 1989) although this sensitivity is dependent on the cultivar (Cramer et al. 1994).

Plant breeding methods are time consuming, slow process, laborious and expensive approach and rely on existing genetic variability. Use of physiological selection criteria can improve the probability of success by making empirical selection more efficient (Noble and Rogers 1992). In this context, screening at the earlier stage can be an easier method to determine salt tolerant genotypes. The main objective of this study was to determine the salt tolerance of 16 tomato germplasm screening them on the basis of visual appearance and to evaluate the growth and yield traits under high salinity condition.

*Author for correspondence: <khabir88@yahoo.com>. ${ }^{1}$ Horticulture Research Centre, Bangladesh Agricultural Research Institute, Gazipur-1701, Bangladesh. ${ }^{2}$ Soil Science Division, Bangladesh Agricultural Research Institute, Gazipur-1701, Bangladesh. 


\section{Materials and Methods}

This experiment was carried out in a solution culture at the Hydroponic Culture House of Horticulture Research Centre, BARI, Gazipur, Bangladesh in winter season of 2010. Sixteen tomato germplasm were used as plant material (Table 1). Seeds were germinated and seedlings were grown in water for 7 days thereafter seedlings at the second true leaf stage were transferred to other plastic containers containing half-Hoagland solution (192 plants, two for each germplasm per container) for 19 days (Hoagland and Arnon 1950). Nutrient solution was renewed at weekly interval throughout the growing period. When the plants were at the fifth-true leaf stage, salt treatment was initiated by adding $\mathrm{NaCl}$ salt to the culture solution. In this experiment, tomato germplasm were tested hydroponically by two levels of salt i.e. 0 (control) and in $120 \mathrm{mM} \mathrm{NaCl}$ with the resultant electrical conductivity (EC) values of $1.4 \pm 0.4$ and $12 \pm 0.7 \mathrm{dS} / \mathrm{m}$, respectively. Tomato is a moderate salt tolerant crop which can withstand in $8-12 \mathrm{dS} / \mathrm{m}$ salinity. The experiment was carried out in a factorial completely randomized design with 3 replications. Two plants were used per germplasm in each replication. The concentration of $\mathrm{NaCl}$ was gradually elevated at $20 \mathrm{mM}$ increment every other day and on day 30; finally the concentration reached to $120 \mathrm{mM}$ equivalent to Ec $12 \pm 0.7 \mathrm{dS} / \mathrm{m}$. The salt level was gradually increased over 4 days to avoid osmotic shock. A set of control plants were simultaneously grown in non salinized solution.

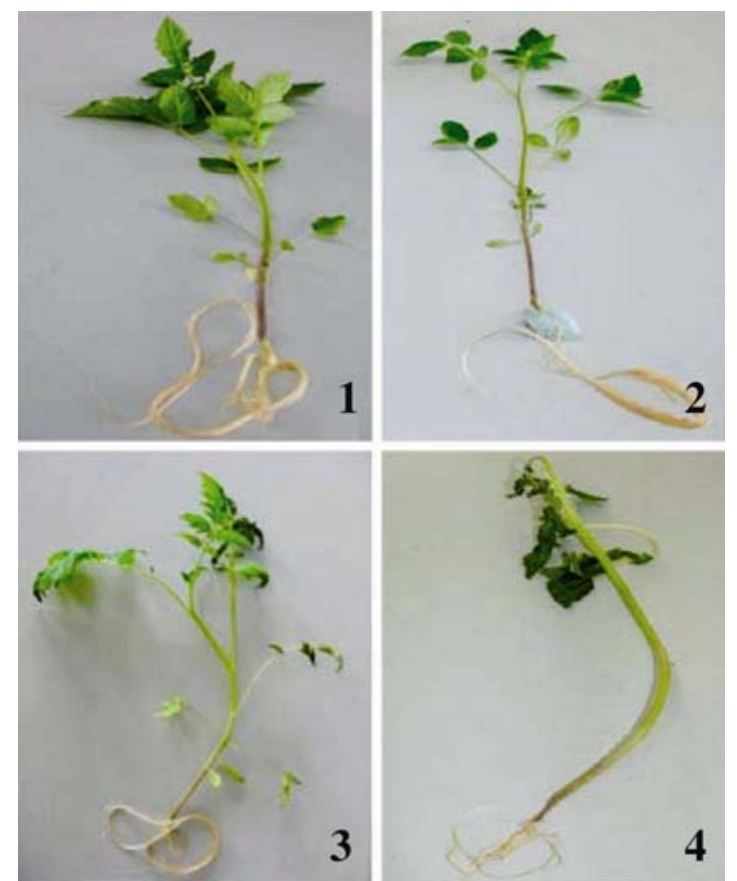

Fig. 1. The salinity scale classes used in the experiment. (0) normal green plant, (1) green leaves with slight inward curly, (2) mild smaller and dry leaves (3) moderate to severe drying damages and (4) all leaves of the plant with drying damages.

Thirty five-day old plants were classified for their salt tolerance by the visual appearance. Plants were rated for severity of salt susceptibility by 0 - 4 scale (Fig. 1). The scale was (0) normal green plants with fully expanded leaves; (1) green leaves with slight inward curly and dry leaves, (2) dry leaves from moderate to severe damages, (3) most leaves with drying damages and (4) all leaves of the plant with drying damages (Dasgan et al. 2002). 
After scale scoring, the plants (1 plant per germplasm from each replication) were harvested and separated into shoots and roots, dried at $65^{\circ} \mathrm{C}$ for $48 \mathrm{hrs}$ and weighed. Dried plants samples were digested following wet oxidation method using nitric and perchloric acids. $\mathrm{Na}, \mathrm{K}$ and $\mathrm{Ca}$ were measured by the flame photometer (Sherwood, M410, Scientific Limited). Fruit yield data were collected timely from remaining plant. Data were analyzed using MSTAT-C (version 2.1, Michigan State University 1991). DMRT was performed to test significant difference among treatment means.

\section{Results and Discussion}

The tomato germplasm were tested with respect to symptom score, shoot and root dry matter, ion concentration and fruit yield.

Sixteen germplasm of tomato were tested for leaf chlorosis and necrosis symptom at 120 $\mathrm{mM} \mathrm{NaCl}$ salinity and they were scored $0-4$. The tomato germplasm tested displayed a large variation $(1.0$ - 3.50) in salt tolerance to treatments based on the visual appearance (Fig. 1). Among the 16 germplasm 5 i.e. BT14, BHTT5, BT7, BT2 and BHT4 produced minimum score $(1.0$ - 1.5) and the lowest score (1.0) was found in BT14 and BHT5 but they were statistically at per (Table 1). At the same time BT7 and BT2 were also statistically similar. The highest score (3.5) was obtained from BT4 followed by WP8 (2.75) and WP2 (2.50). The lowest leaf chlorosis and necrosis symptom score were found in BT14 and BHT5 which might be due to its genetic makeup. Chookhampaeng et al. (2007) observed that salinity tolerance score of 13 tomato genotypes were 1.0 - 3.75. Oztekin and Tuzel (2011) observed that screening of tomato genotypes based on severity of symptoms at early stage of development.

Table 1. Leaf chlorosis and necrosis symptom score $(0$ - 4) of 16 tomato germplasm grown at $120 \mathrm{mM} \mathrm{NaCl}$ salinity.

\begin{tabular}{lll}
\hline Germplasm & Status & Score* \\
\hline BT14 (BARI Tomato 14) & Approved variety & $1.00 \mathrm{a}$ \\
BHT5 (BARI Hybrid Tomato 5) & Approved Hybrid variety & $1.00 \mathrm{a}$ \\
BT7 (BARI Tomato 7) & Approved variety & $1.25 \mathrm{~b}$ \\
BT2 (BARI Tomato 2) & $"$ & $1.25 \mathrm{~b}$ \\
BHT4 (BARI Hybrid Tomato 4) & Approved Hybrid variety & $1.50 \mathrm{bc}$ \\
BT9 (BARI Tomato 9) & Approved variety & $2.00 \mathrm{~d}$ \\
BT8 (BARI Tomato 8) & $"$ & $2.00 \mathrm{~d}$ \\
BT11 (BARI Tomato 11) & $"$ & $2.25 \mathrm{de}$ \\
BHT3 (BARI Hybrid Tomato 3) & Approved Hybrid variety & $2.25 \mathrm{de}$ \\
BT3 (BARI Tomato 3) & Approved variety & $2.50 \mathrm{ef}$ \\
WP7 & Line & $2.25 \mathrm{de}$ \\
C71 & $"$ & $2.50 \mathrm{ef}$ \\
C51 & $"$ & $2.50 \mathrm{ef}$ \\
WP2 & $"$ & $2.50 \mathrm{ef}$ \\
WP8 & $"$ & $2.75 \mathrm{f}$ \\
BT4 (BARI Tomato 4) & Approved variety & $3.50 \mathrm{~g}$ \\
\hline
\end{tabular}

Means followed by the same letter are statistically not significant (DMRT, p $=0.05)$. *The salinity scale classes used in the experiment. (0) normal plant, (1) slight, (2) mild (3) severe and (4) very severe. 
The shoot and root dry weight of tomato germplasm are presented in Table 2. In control condition, tomato germplasm did not produce any significant variation in shoot and root dry weight. At $120 \mathrm{mM} \mathrm{NaCl}$, shoot and root dry weight were found to differ significantly among the tomato germplasm. The highest shoot dry weight was obtained in BT14 (3.15 g/plant) followed by BHT5 (3.12 g/plant). But they were statistically at per. At the same time the germplasm BT7, BT2 and BHT4 produced shoot dry weight 2.38, 2.49 and $2.45 \mathrm{~g} /$ plant, respectively and they were statistically similar and lower from both BT14 and BHT5. Rest of the germplasm viz BT9, BT8, BT11, BHT3, BT3, WP7, C71, C51 and WP2 were produced lower shoot dry weight from BT7, BT2 and BHT4 but higher from both WP8 and BT4 and their dry weight were basically the same at high salinity. Among the germplasm BT4 took lowest ( $0.75 \mathrm{~g} / \mathrm{plant})$ shoot dry weight compared to others before said germplasm which was similar to WP8 (1.25 g/plant).

Table 2. Shoot and root dry weight of tomato germplasm grown under saline condition.

\begin{tabular}{|c|c|c|c|c|c|c|c|}
\hline \multirow[t]{2}{*}{ Germplasm } & \multicolumn{3}{|c|}{ Shoot DW (g/plant) } & \multicolumn{3}{|c|}{ Root DW (g/plant) } & \multirow{2}{*}{$\begin{array}{l}\text { Fruit yield } \\
\text { (kg/plant) }\end{array}$} \\
\hline & Control & $\begin{array}{c}120 \mathrm{mM} \\
\mathrm{NaCl}\end{array}$ & $\begin{array}{l}\text { \% reduction } \\
\text { in shoot DW }\end{array}$ & Control & $\begin{array}{c}120 \mathrm{mM} \\
\mathrm{NaCl}\end{array}$ & $\begin{array}{l}\% \text { reduction } \\
\text { in root DW }\end{array}$ & \\
\hline BT14 & 3.84 & $3.15 \mathrm{a}$ & 17.97 & 2.45 & $2.12 \mathrm{a}$ & 13.47 & $1.55 \mathrm{a}$ \\
\hline BHT5 & 3.85 & $3.12 \mathrm{a}$ & 18.96 & 2.52 & $2.15 \mathrm{a}$ & 14.68 & $1.50 \mathrm{a}$ \\
\hline BT7 & 3.7 & $2.58 \mathrm{~b}$ & 30.27 & 2.22 & $1.62 \mathrm{~b}$ & 27.03 & $1.20 \mathrm{~b}$ \\
\hline BT2 & 3.63 & $2.49 \mathrm{~b}$ & 31.40 & 2.35 & $1.68 \mathrm{~b}$ & 28.51 & $1.16 \mathrm{~b}$ \\
\hline BHT4 & 3.69 & $2.45 \mathrm{~b}$ & 33.60 & 2.15 & $1.46 \mathrm{~b}$ & 32.09 & $1.10 \mathrm{~b}$ \\
\hline ВT9 & 3.62 & $1.74 \mathrm{c}$ & 51.93 & 2.00 & $1.10 \mathrm{c}$ & 45.00 & $0.91 \mathrm{c}$ \\
\hline ВТ8 & 3.73 & $1.79 \mathrm{c}$ & 52.01 & 2.10 & $1.09 \mathrm{c}$ & 48.10 & 0.90 c \\
\hline BT11 & 3.59 & $1.64 \mathrm{~cd}$ & 54.32 & 1.60 & $0.89 \mathrm{~cd}$ & 44.38 & $0.71 \mathrm{~cd}$ \\
\hline ВНТЗ & 3.44 & 1.55 c-e & 54.94 & 1.97 & $0.88 \mathrm{~cd}$ & 55.33 & 0.82 c \\
\hline ВT3 & 3.57 & 1.54 c-e & 56.86 & 1.55 & $0.86 \mathrm{~d}$ & 44.52 & $0.69 \mathrm{~d}$ \\
\hline WP7 & 3.72 & 1.49 c-e & 59.95 & 1.75 & 0.78 de & 55.43 & $0.65 \mathrm{~d}$ \\
\hline C71 & 3.65 & 1.45 c-e & 60.27 & 1.95 & $0.75 \mathrm{de}$ & 61.54 & $0.67 \mathrm{~d}$ \\
\hline C51 & 3.68 & $1.33 \mathrm{c}-\mathrm{f}$ & 63.86 & 1.91 & $0.67 \mathrm{~d}-\mathrm{f}$ & 64.92 & $0.26 \mathrm{e}$ \\
\hline WP2 & 3.55 & $1.27 \mathrm{c}-\mathrm{f}$ & 64.23 & 1.08 & 0.48 ef & 55.56 & - \\
\hline WP8 & 3.58 & $1.25 \mathrm{~d}-\mathrm{f}$ & 65.08 & 1.09 & 0.45 ef & 58.72 & - \\
\hline BT4 & 3.08 & $0.75 \mathrm{~g}$ & 75.65 & 1.05 & $0.18 \mathrm{~g}$ & 82.86 & - \\
\hline $\begin{array}{l}\text { Level of } \\
\text { significance }\end{array}$ & NS & $* *$ & & NS & $* *$ & & $* *$ \\
\hline
\end{tabular}

NS $=$ Non significant, $* *=$ Significant at $5 \%$ level. Means followed by the same letter are statistically not significant (DMRT, $\mathrm{p}=0.05$ ).

Similar trend was observed in case of root dry weight. The highest root dry weight (2.15 g/plant) was exhibited by BHT14 followed by BT14 (2.12 g/plant). These were statistically similar. The rest of the germplasm were significantly produced lower root dry weight while the lowest (0.18 g/plant) root dry weight was obtained from BT4. In addition, BT7, BT2 and BHT4 attained root dry weight 1.62, 1.68 and $1.46 \mathrm{~g} / \mathrm{plant}$, respectively and they were statistically at par and these were significantly lower from both BT14 and BHT5 and higher than BT9, BT8, BT11 and BHT3 but these BT9, BT8, BT11 and BHT3 were statistically identical. BT3, WP7, C51 and C71 exhibited lower root DW than BT9, BT8, BT11 and BHT3 and these statistically similar germplasm higer from both WP2 and WP8 and both of them also were statistically similar. The physical growth parameters such as shoot and root dry weight are more correlated with crop salt tolerance at early growth stages and can be used as screening/selection criteria (Ibrahim 2003). 
Foolad (1996) have indicated that shoot growth under high salinity relative to control is the best practical indicator of salt tolerance in tomato.

Shoot and root DW of BT14 and BHT5 showed only 17.96, 18.97 and 13.47, 14.68\%, respectively reduction from the control plant than others and followed by BT7, BT2 and BHT4. In contrast, the most sensitive germplasm, BT4 (scale class 3.5) suffered from 75.65 and $82.86 \%$ reduction in shoot and root DW, respectively. Similar results were also reported by Turhan and Seniz (2012) in which a large variation in root and shoot dry weight was observed between 12 genotypes under increasing salinity.

However, significant relations were found between shoot-root dry weights and the salinity scale classes. Highly significant correlations were found between per cent reduction in shoot DW with the scale classes $\left(r^{2}=0.945^{* *}\right.$, Fig. $\left.2 a\right)$ and root DW with the scale classes $\left(r^{2}=0.903^{* *}\right.$, Fig. $2 \mathrm{~b})$. The relationship between salt tolerance, as indicated by scale classes and per cent reduction of plant biomass production were found strong significantly positive correlation which indicated that growth of tomato plants is highly dependent on salt tolerance. This correlation was contradictory with Dasgan et al. (2002) which may be due to large differences in growth potential of different genotypes.

The fruit weight of tomato showed a significant variation among the germplasm and in general there was a significant decrease from the control to the high salt treated plants on fruits yield (Table 2). The decrease was less prominent on BT14 and BHT5. The highest fruit yield was obtained in BT14 (1.55 kg/plant) followed by BHT5 (1.50 kg/plant) but they were statistically identical. At the same time BT7, BT2 and BHT4 produced fruit yield 1.20, 1.16 and $1.10 \mathrm{~kg} / \mathrm{plant}$, respectively and they were statistically similar. Rest of the germplasm produced lower fruit yield and their fruit yield were basically the same at high salinity while the lowest $(0.26 \mathrm{~kg} / \mathrm{plant})$ fruit yield was obtained from C71. BT4, WP8 and WP7 did not get any fruit yield with high salinity. Similar results were reported by Siddiky et al. (2012) in which a large variation in fruit yield was observed of between 10 tomato genotypes under high salinity and fruit yield were less than $60 \%$ from the control salinity.

The shoot ion concentration of tomato germplasm is presented in Table 3. In control condition, tomato germplasm did not produce any significant variation in $\mathrm{Na}^{+}$concentration. On average, the $\mathrm{K}^{+} / \mathrm{Na}^{+}$and $\mathrm{Ca}^{2+} / \mathrm{Na}^{+}$ratios were very similar between sensitive and tolerant germplasm when $\mathrm{NaCl}$ was not supplied. In comparison with the control plants, the tissues of salttreated plants accumulated more $\mathrm{Na}^{+}$but less $\mathrm{K}^{+}$and $\mathrm{Ca}^{2+}$, due to salinity induces $\mathrm{K}^{+}$, and $\mathrm{Ca}^{2+}$ deficiencies by lowering $\mathrm{K}^{+}$, and $\mathrm{Ca}^{2+}$ uptake (Singh et al. 2004), resulting in lowered $\mathrm{K}^{+} / \mathrm{Na}^{+}$ and $\mathrm{Ca}^{2+} / \mathrm{Na}^{+}$ratios.

Under salinity stress the $\mathrm{Na}^{+}$concentration produced by all germplasm, positively significant corelated $\left(r=0.883^{*}\right)$ with symptom scale classes (Fig. 2e). The highest potassium contents at 120 mM salinity level had resulted in significantly higher $\mathrm{K}^{+} / \mathrm{Na}^{+}$ratio in BT14 (1.79) and BHT5 (1.70) followed by BT7 (1.42), BT2 (1.35) and BHT4 (1.10) while the most sensitive germplasm BT4 (0.25), these changes were always smaller. Similar trend of result also found in calcium content. The highest calcium contents at $120 \mathrm{mM}$ salinity level had resulted in significantly higher $\mathrm{Ca}^{2+} / \mathrm{Na}^{+}$ratio in BT14 (1.15) and BHT5 (1.11) but they are statistically at per, followed by BT7 (0.82), BT2 (0.78), BHT4 (0.62) and BT9 (0.60). BT11, BHT3, BT3 and WP7 produced the lower ratio and statistically they are similar while the most sensitive germplasm BT4 obtained the lowest ratio (0.25). However, the $\mathrm{K}^{+} / \mathrm{Na}^{+}$and $\mathrm{Ca}^{2+} / \mathrm{Na}^{+}$ratios showed very significantly negative correlation ( $r=0.820^{*}$, Fig. 2c and $r=0.898^{*}$, Fig. $2 d$ ) with the salinity scale classes. The study suggested that tissue ion content and ion selectivity were good selection criteria for breeding for salt tolerance in tomato (Ahsan et al. 2000). 

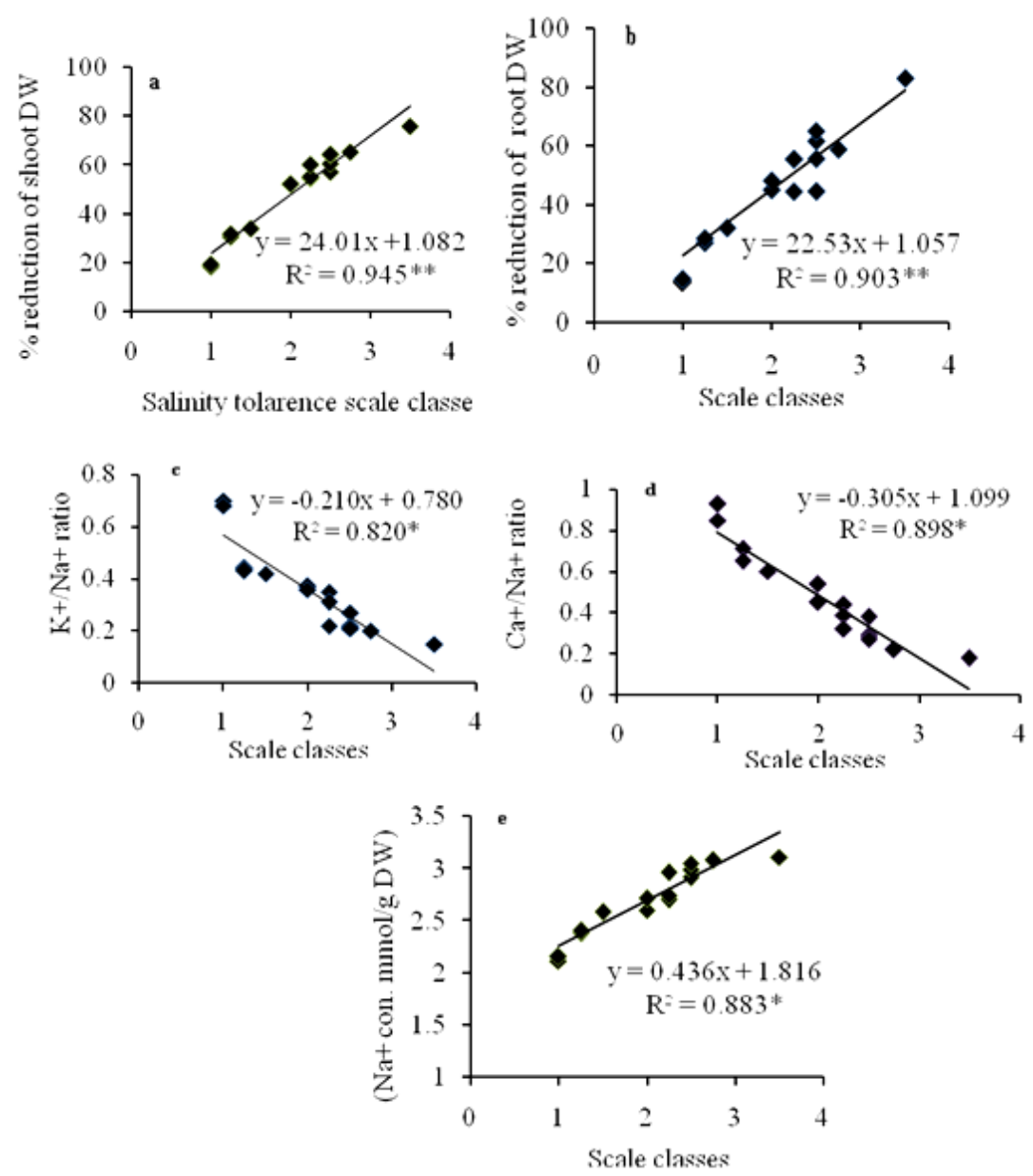

Fig. 2. Relation between the salinity scale classes: (a) \% reduction of shoot DW, (b) \% reduction of root DW, (c) $\mathrm{K}^{+} / \mathrm{Na}^{+}$ratios, (d) $\mathrm{Ca}^{2+} / \mathrm{Na}^{+}$ratios and (e) $\mathrm{Na}^{+}$concentration of the tomato germplasm grown under saline condition. $\mathrm{n}=16,{ }^{*} \mathrm{p}=0.05$ and ${ }^{*} \mathrm{p}=0.01$. Increasing scale classes from $1-4$ indicate increases in salt damages.

Characteristics like dry matter production, $\mathrm{Na}^{+}$accumulation, $\mathrm{K}^{+} / \mathrm{Na}^{+}$ratio and $\mathrm{Ca}^{2+} / \mathrm{Na}^{+}$ratio have been considered a useful guide to assess salt tolerance and selection of genotypes in saline soils (Santa-Maria and Epstein 2001). In high salinity, $\mathrm{K}^{+} / \mathrm{Na}^{+}$and $\mathrm{Ca}^{2+} / \mathrm{Na}^{+}$ratios were decreased from control but less decreased in BT14 and BHT5 (Table 3). Houshmand et al. (2005) found that the tolerant wheat genotypes had higher shoot $\mathrm{K}^{+} / \mathrm{Na}^{+}$than the sensitive ones and strong correlation was found between shoot $\mathrm{K}^{+} / \mathrm{Na}^{+}$and dry matter in plants treated with $150 \mathrm{mM} \mathrm{NaCl}$. Physiological impairments caused by $\mathrm{Na}^{+}$toxicity include disruption of $\mathrm{K}^{+}$and $\mathrm{Ca}^{2+}$ nutrition, development of water stress and induction of oxidative cell damage. Therefore, maintenance of low $\mathrm{Na}^{+}$concentration by preventing $\mathrm{Na}^{+}$uptake or regulating $\mathrm{Na}^{+}$homeostasis in the cells by higher $\mathrm{K}^{+} / \mathrm{Na}^{+}$ratio or sequestering $\mathrm{Na}$ ions in vacuole are the major strategies of plants against $\mathrm{Na}^{+}$stress (Zhu 2001, Rengel 1992). 
Table 3. Different ion concentration in the shoot of the tomato germplasm.

\begin{tabular}{|c|c|c|c|c|c|c|c|c|c|c|}
\hline \multirow{3}{*}{ Germplasm } & \multicolumn{10}{|c|}{$\mathrm{NaCl}$ concentration } \\
\hline & \multicolumn{5}{|c|}{ Control } & \multicolumn{5}{|c|}{$120 \mathrm{mM}$} \\
\hline & $\mathrm{Na}^{+}$ & $\mathrm{K}^{+}$ & $\mathrm{Ca}^{2+}$ & $\begin{array}{l}\mathrm{K}^{+} / \\
\mathrm{Na}^{+}\end{array}$ & $\begin{array}{c}\mathrm{Ca}^{2+} / \\
\mathrm{Na}^{+}\end{array}$ & $\mathrm{Na}^{+}$ & $\mathrm{K}^{+}$ & $\mathrm{Ca}^{2+}$ & $\begin{array}{l}\mathrm{K}^{+} / \\
\mathrm{Na}^{+}\end{array}$ & $\begin{array}{c}\mathrm{Ca}^{2+} / \\
\mathrm{Na}^{+}\end{array}$ \\
\hline BT14 & 0.43 & $3.59 c$ & 3.30b & $8.35 \mathrm{a}$ & $7.67 \mathrm{a}$ & $1.11 \mathrm{~h}$ & $1.99 a$ & $1.28 \mathrm{a}$ & $1.79 a$ & $1.15 \mathrm{a}$ \\
\hline BHT5 & 0.53 & 4.37ab & $4.00 \mathrm{a}$ & $8.25 \mathrm{a}$ & $7.55 a$ & $1.05 \mathrm{~h}$ & $1.89 a$ & $1.23 \mathrm{a}$ & $1.70 \mathrm{a}$ & $1.11 \mathrm{a}$ \\
\hline BT7 & 0.61 & $4.76 a$ & 3.89a & $7.80 \mathrm{~b}$ & $6.38 \mathrm{~b}$ & $1.25 \mathrm{~g}$ & $1.78 \mathrm{~b}$ & 1.19ab & $1.42 \mathrm{~b}$ & $0.82 b$ \\
\hline BT2 & 0.65 & $5.03 a$ & $4.04 \mathrm{a}$ & $7.75 \mathrm{~b}$ & $6.21 b$ & $1.30 \mathrm{~g}$ & $1.76 \mathrm{~b}$ & 1.18ab & $1.35 b$ & $0.78 b$ \\
\hline BHT4 & 0.68 & $5.00 \mathrm{a}$ & $4.00 \mathrm{a}$ & 7.35bc & $5.88 \mathrm{bc}$ & $1.45 f$ & $1.60 \mathrm{c}$ & $0.90 \mathrm{c}$ & $1.10 \mathrm{bc}$ & $0.62 b c$ \\
\hline BT9 & 0.70 & 4.47ab & $3.51 b$ & 6.38d & $4.87 c$ & $1.48 \mathrm{f}$ & $1.55 \mathrm{c}$ & $0.89 c$ & $1.05 c$ & $0.60 \mathrm{bc}$ \\
\hline BT8 & 0.63 & $3.98 c$ & $2.93 c$ & $6.32 \mathrm{~d}$ & 4.65cd & $1.50 \mathrm{f}$ & $1.43 d$ & $0.81 \mathrm{~cd}$ & $0.95 c$ & $0.54 \mathrm{~cd}$ \\
\hline BT11 & 0.57 & $3.60 c$ & $2.50 \mathrm{~d}$ & $6.31 \mathrm{~d}$ & 4.38cd & $1.65 \mathrm{e}$ & $1.40 \mathrm{~d}$ & $0.84 \mathrm{c}$ & $0.85 c d$ & $0.5 \mathrm{~cd}$ \\
\hline ВНT3 & 0.58 & $3.51 \mathrm{c}$ & $2.41 d$ & 6.05de & 4.15de & $1.66 \mathrm{e}$ & $1.20 \mathrm{e}$ & $0.75 d$ & $0.72 \mathrm{~d}$ & $0.45 \mathrm{~d}$ \\
\hline ВT3 & 0.47 & 2.81cd & 1.93de & $5.98 \mathrm{e}$ & 4.11de & $1.69 \mathrm{e}$ & $1.13 \mathrm{e}$ & $0.71 d$ & $0.60 \mathrm{~d}$ & $0.42 \mathrm{~d}$ \\
\hline WP7 & 0.50 & $2.88 \mathrm{~cd}$ & 1.91de & $5.75 \mathrm{ef}$ & $3.85 \mathrm{e}$ & $1.71 \mathrm{e}$ & $0.94 \mathrm{f}$ & $0.70 \mathrm{~d}$ & $0.50 \mathrm{e}$ & $0.41 d$ \\
\hline C71 & 0.49 & $2.70 \mathrm{~d}$ & 1.85de & $5.50 \mathrm{ef}$ & $3.78 \mathrm{e}$ & $1.85 \mathrm{~cd}$ & $0.89 \mathrm{f}$ & $0.65 \mathrm{e}$ & $0.48 \mathrm{e}$ & $0.35 \mathrm{e}$ \\
\hline C51 & 0.53 & $2.87 \mathrm{~cd}$ & 1.95de & $5.41 \mathrm{f}$ & $3.68 \mathrm{e}$ & $1.86 \mathrm{~cd}$ & $0.73 g$ & $0.63 e$ & $0.39 \mathrm{f}$ & $0.34 \mathrm{e}$ \\
\hline WP2 & 0.46 & $2.42 \mathrm{e}$ & $1.67 \mathrm{e}$ & $5.27 f$ & 3.62ef & $1.95 c$ & $0.56 \mathrm{~h}$ & $0.60 \mathrm{e}$ & $0.30 \mathrm{f}$ & $0.31 \mathrm{e}$ \\
\hline WP8 & 0.48 & 2.51de & $1.72 \mathrm{e}$ & $5.22 \mathrm{f}$ & 5.59ef & $2.10 \mathrm{~b}$ & $0.61 \mathrm{~h}$ & $0.61 \mathrm{e}$ & $0.29 f g$ & $0.29 \mathrm{e}$ \\
\hline BT4 & 0.45 & $1.96 \mathrm{f}$ & $1.58 \mathrm{e}$ & $4.37 \mathrm{~g}$ & $3.52 \mathrm{f}$ & $2.52 \mathrm{a}$ & $0.63 \mathrm{~h}$ & $0.43 \mathrm{f}$ & $0.25 \mathrm{~g}$ & $0.17 \mathrm{f}$ \\
\hline $\begin{array}{l}\text { Level of } \\
\text { significance }\end{array}$ & NS & $* *$ & $* *$ & $* *$ & $* *$ & $* *$ & $* *$ & $* *$ & $* *$ & $* *$ \\
\hline
\end{tabular}

NS $=$ Non significant, $* *=$ Significant at $5 \%$ level. Means followed by the same letter are statistically not significant (DMRT, $\mathrm{p}=0.05$.

By screening out of 16 tomato germplasm, 2: BT14 (BARI Tomato 14) and BHT5 (BARI Hybrid Tomato 5), reflected good performance in order to symptom score, plant dry matter production, ion concentration and fruit yield under saline conditions, and these 2 germplasm can be used popularly in the saline zones of Bangladesh to have better production.

\section{References}

Ahsan M, Khalig I and Mehdi SS 2000. Phsiogenetic and breeding aspect of salinity tolerance in bread wheat: a review. Pak. J. of Bio. Sci. 3(9): 1354-1363.

Ashraf M and Foolad MR 2007. Improving plant abiotic-stress resistance by exogenous application of osmoprotectants glycine betaine and proline. Environ. Expt. Bot. 59: 206-216.

Ayers RS and Westcot DW 1989. Water Quality for Agriculture. FAO Irrigation and Drainage Paper 29, Rome.

Chookhampaeng S, Pattanagul W and Theerakulpisut P 2007. Screening some tomato commercial cultivars from Thiland for salinity tolerance. Asian J. Plant Sci. 6(5): 788-794.

Cramer GR, Alberico GJ and Schmidt C 1994. Leaf expansion limits dry matter accumulation of salt stressed maize. Aust. J. Plant Physiol. 21: 663-674.

Dasgan HY, Aktas H, Abak K and Cakmak I 2002. Determination of screening techniques to salt tolerance in tomatoes and investigation of genotype responses. Plant Sci. 163: 695-703. 
FAO 2011. Global network on integrated soil management for sustainable use of salt affected soils. Rome, Italy: FAO Land and Plant Nutr. Manag. Service. http://www.fao.org/ag/agl/agll/spush

Foolad MR 1996. Genetic analysis of salt tolerance during vegetative growth in tomato Lycopersicon esculentum Mill. Plant Breed. 115: 245-250.

Hoagland DR and Arnon AI 1950. The water-culture method for growing plants without soil. California Agricultural Experiment Station Circular, 347, Berkeley, p. 32.

Houshmand S, Arzanib A, Maibodyb SAM and Feizi M 2005. Evaluation of salt-tolerant genotypes of durum wheat derived from in vitro and field experiments. Field Crop Res. 91: 345-354.

Ibrahim, M. 2003. Salt Tolerance Studies on Cotton. M. Sc. thesis, Institute of Soil and Environmental Sciences, Univ. Agri., Faisalabad, Pakistan.

Noble CL and Rogers ME 1992. Arguments for the use of physiological criteria for improving the salt tolerance in crops. Plant Soil 146: 99-107.

Oztekin GB and Tuzel Y 2011. Comparative salinity responses among tomato Genotypes and rootstocks. Pak. J. Bot. 43(6): 2665-2672.

Rengel Z 1992. The role of calcium in salt toxicity. Plant and Cell Environ. 15: 625-632.

Santa-Maria GE and Epstein E 2001. Potasium/sodium selectivity in wheat and the amphiploid cross wheat $\times$ Lophophyrum elongatum. Plant Sci. 160: 523-534.

Siddiky MA, Sardar PK, Hossain MM, Khan MS and Khabir Uddin M 2012. Screening of Different Tomato Varieties in Saline Areas of Bangladesh. Int. J. Agril. Res. Innov. \& Tech. 2(1): 13-18.

Singh AL, Basu MS and Singh NB 2004. Mineral Disorders of Groundnut. Junagadh, India: National Research Center for Groundnut (ICAR). p. 85.

SRDI 2010. Salinity of Bangladesh. Soil Resources and Development Institute. MoA, Government of People Republic of Bangladesh. December, 2010.

Turhan A and Seniz V 2012. Salt tolerance during vegetative growth in cross of tomato and effect of cytoplasm in response to salt tolerance. Bulgarian J. Agric. Sci. 18(2): 207-218.

Zhu JK 2001. Plant salt tolerance. Trends Plant Sci. 6: 66-71.

(Manuscript received on 20 July, 2014; revised on 14 September, 2014) 